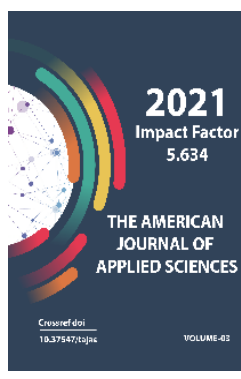

Journal Website: https://theamericanjou rnals.com/index.php/ta jas

Copyright: Original content from this work may be used under the terms of the creative commons attributes 4.0 licence.

\section{Research In The Field Of Intensive Oxidative Roasting Of Molybdenum Sludges}

\author{
Behzod Tolibov \\ PhD, Associate Professor, Navoi State Mining Institute, Navoi, Uzbekistan
}

Abdurashid Hasanov

DSc, Professor, Deputy Chief Engineer Of JSC Almalyk Mining And Metallurgical Combine, Almalyk, Uzbekistan

\title{
ABSTRACT
}

The article deals with the issues of oxidative roasting of sulfide molybdenum-containing materials. The main indicators of production, the recommended parameters for optimal oxidation of sulfides are given as a result of experiments. Also, theoretical foundations and practical data are presented, conclusions on the oxidation of molybdenum sulfide compounds are analyzed and summarized. As a result of numerous laboratory experiments, conclusions have been drawn for the production.

\section{KEYWORDS}

Sulfide, Molybdenum, Molybdenite Concentrates, Oxidative Roasting, Extraction, Moisture, Desulfurization, Oxidation Degree.

\section{INTRODUCTION}

At present, molybdenite concentrates are processed mainly according to the technology, including oxidative roasting at temperatures of $580-620^{\circ} \mathrm{C}$ to obtain a cinder, which (depending on the quality of the concentrate) is either immediately sent to ferromolybdenum smelting, or is subjected to hydrometallurgical processing [16; c.15]. The disadvantage of this technology is the ecologically inexpediency of the scheme, since with the use of this processing scheme, sulfur dioxide is emitted in large quantities into the atmosphere and the costs of eliminating this problem. Scientists Aleksandrov P.V., Medvedev A.S., Kadirov A.A., Imideev V.A. propose to replace the oxidizing roasting with the oxidizing-chlorinating one, which allows to reduce the release of sulfur dioxide into the atmosphere, meanwhile, to reduce the firing temperature to $450{ }^{\circ} \mathrm{C}$. The extraction of molybdenum into the cinder 
during three parallel experiments was different for reasons not yet established, apparently associated with the firing mechanism. As can be seen from the data presented, $\sim 60-75 \%$ of Mo remains in the cinder, the rest of its amount is chlorinated and sublimated in the composition of chlorides and oxychlorides and is almost completely captured in the settling chamber and absorbers [17; c.12-16].

\section{THE MAIN FINDINGS AND RESULTS}

Low-temperature intensive firing of sulphide molybdenum cakes in a new experimentalindustrial installation for oxidative firing was carried out at a temperature of $450^{\circ} \mathrm{C}$ with a moisture content of the supplied material $\mathrm{W}=$
$18 \%$, with a process duration of 30 to $120 \mathrm{~min}$. Samples were taken every 15 min to determine the composition of the fired material. The results of the experiments are shown in Table 1. It can be seen from the table that when the material is kept inside the installation for about 30 minutes, the sulfide sulfur is removed $41.05 \%$, i.e., initially the sulfur content in the initial sample was $1.52 \%$, after processing, o remained. nine \%. The following results show that with an increase in the duration of the process, the oxidation state of sulfides increases. Further experiments were carried out under different conditions, i.e. at different humidity of the supplied material, at different temperatures inside the oven, therefore, in different durations of the process. The results are presented in tables 1 .and 2.

Table 1

Results of experiments on oxidative roasting of molybdenum cakes to determine the optimal mode. $\mathrm{T}=450^{\circ} \mathrm{C}, \mathrm{W}=18 \%$

\begin{tabular}{|c|c|c|c|c|c|c|}
\hline $\begin{array}{c}\text { Sample } \\
\text { No. }\end{array}$ & $\begin{array}{c}\text { Content Mo, } \\
\%\end{array}$ & Content S, \% & $\begin{array}{c}\text { Duration of } \\
\text { the process, } \\
\text { minutes }\end{array}$ & $\begin{array}{c}\text { Content S, } \\
\text { after } \\
\text { roasting } \\
\text { process, } \%\end{array}$ & $\begin{array}{c}\text { Desul- } \\
\text { furization } \\
\text { degree, \% }\end{array}$ & $\begin{array}{c}\text { Extraction } \\
\text { Mo, \% }\end{array}$ \\
\hline 1 & 8,72 & 1,52 & 30 & 0,90 & 41,05 & 66,8 \\
\hline 2 & 8,72 & 1,52 & 45 & 0,87 & 42,60 & 68,4 \\
\hline 3 & 8,72 & 1,52 & 60 & 0,85 & 44,14 & 70,0 \\
\hline 4 & 8,72 & 1,52 & 75 & 0,83 & 45,69 & 71,6 \\
\hline 5 & 8,72 & 1,52 & 90 & 0,80 & 47,24 & 73,2 \\
\hline 6 & 8,72 & 1,52 & 105 & 0,78 & 48,78 & 74,8 \\
\hline
\end{tabular}


The American Journal of Applied sciences

(ISSN - 2689-0992)

Published: September 30, 2021 | Pages: 57-66

2021: 5.634

Doi: https://doi.org/10.37547/tajas/Volume03lssue09-09

OCLC - 1121105553

\begin{tabular}{|c|c|c|c|c|c|c|}
\hline $\begin{array}{c}\text { Sample } \\
\text { No. }\end{array}$ & $\begin{array}{c}\text { Content Mo, } \\
\%\end{array}$ & Content S, \% & $\begin{array}{c}\text { Duration of } \\
\text { the process, } \\
\text { minutes }\end{array}$ & $\begin{array}{c}\text { Content S, } \\
\text { after } \\
\text { roasting } \\
\text { process, } \%\end{array}$ & $\begin{array}{c}\text { Desul- } \\
\text { furization } \\
\text { degree, \% }\end{array}$ & $\begin{array}{c}\text { Extraction } \\
\text { Mo, \% }\end{array}$ \\
\hline 7 & 8,72 & 1,52 & 120 & 0,74 & 51,50 & 75,9 \\
\hline 8 & 8,72 & 1,52 & 135 & 0,74 & 51,50 & 76,0 \\
\hline
\end{tabular}

Table 2

Results of experiments on oxidative roasting of molybdenum cakes to determine the optimal mode. $\mathrm{T}=500^{\circ} \mathrm{C}, \mathrm{W}=18 \%$

\begin{tabular}{|c|c|c|c|c|c|c|}
\hline $\begin{array}{c}\text { Sample } \\
\text { No. }\end{array}$ & $\begin{array}{c}\text { Content Mo, } \\
\%\end{array}$ & Content S, \% & $\begin{array}{c}\text { Duration of } \\
\text { the process, } \\
\text { minutes }\end{array}$ & $\begin{array}{c}\text { Content S, } \\
\text { after } \\
\text { roasting } \\
\text { process, } \%\end{array}$ & $\begin{array}{c}\text { Desul- } \\
\text { furization } \\
\text { degree, } \%\end{array}$ & $\begin{array}{c}\text { Extraction } \\
\text { Mo, \% }\end{array}$ \\
\hline 1 & 8,61 & 1,47 & 30 & 0,74 & 49,52 & 75,5 \\
\hline 2 & 8,61 & 1,47 & 45 & 0,73 & 50,61 & 75,9 \\
\hline 3 & 8,61 & 1,47 & 60 & 0,71 & 51,70 & 76,3 \\
\hline 4 & 8,61 & 1,47 & 75 & 0,69 & 52,79 & 76,7 \\
\hline 5 & 8,61 & 1,47 & 90 & 0,68 & 53,88 & 77,1 \\
\hline 6 & 8,61 & 1,47 & 105 & 0,66 & 54,97 & 77,5 \\
\hline 7 & 8,61 & 1,47 & 120 & 0,65 & 55,60 & 77,9 \\
\hline
\end{tabular}

The results of experiments with the moisture content of the supplied material of $18 \%$ at temperatures of $550^{\circ} \mathrm{C}, 600^{\circ} \mathrm{C}, 650^{\circ} \mathrm{C}$ are given in Appendix 2. Figure 1 shows the data of laboratory studies in the form of a graph. In the graph, the temperature inside the furnace ranges from $450^{\circ} \mathrm{C}$ to $650^{\circ} \mathrm{C}$, the duration of the process ranges from 30 to 135 minutes. Only 
The American Journal of Applied sciences

the moisture content of the supplied material is the same everywhere.

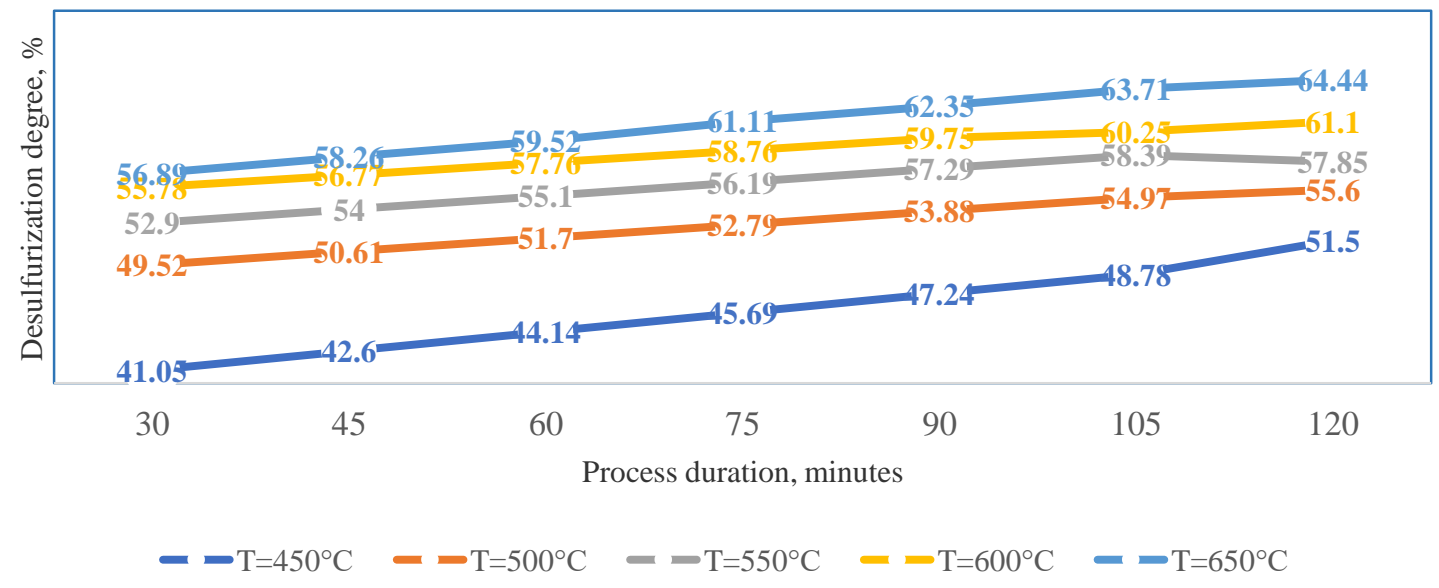

Pic.1 Influence of temperature and duration of the process on the oxidation state of sulfides

Figure 2 shows the data on the extraction of the main element, while the dependence of the degree of extraction on the duration of the process and the temperature inside the unit is revealed. Here you can see what the effective condition is, the temperature inside the unit is $600^{\circ} \mathrm{C}$ and the process time is 90 minutes.
Next, experiments were carried out with oxidative firing at different temperatures and duration of the process at a moisture content of the supplied material $W=16 \%$. The most positive results were observed when the temperature inside the furnace was $500-550^{\circ} \mathrm{C}$.

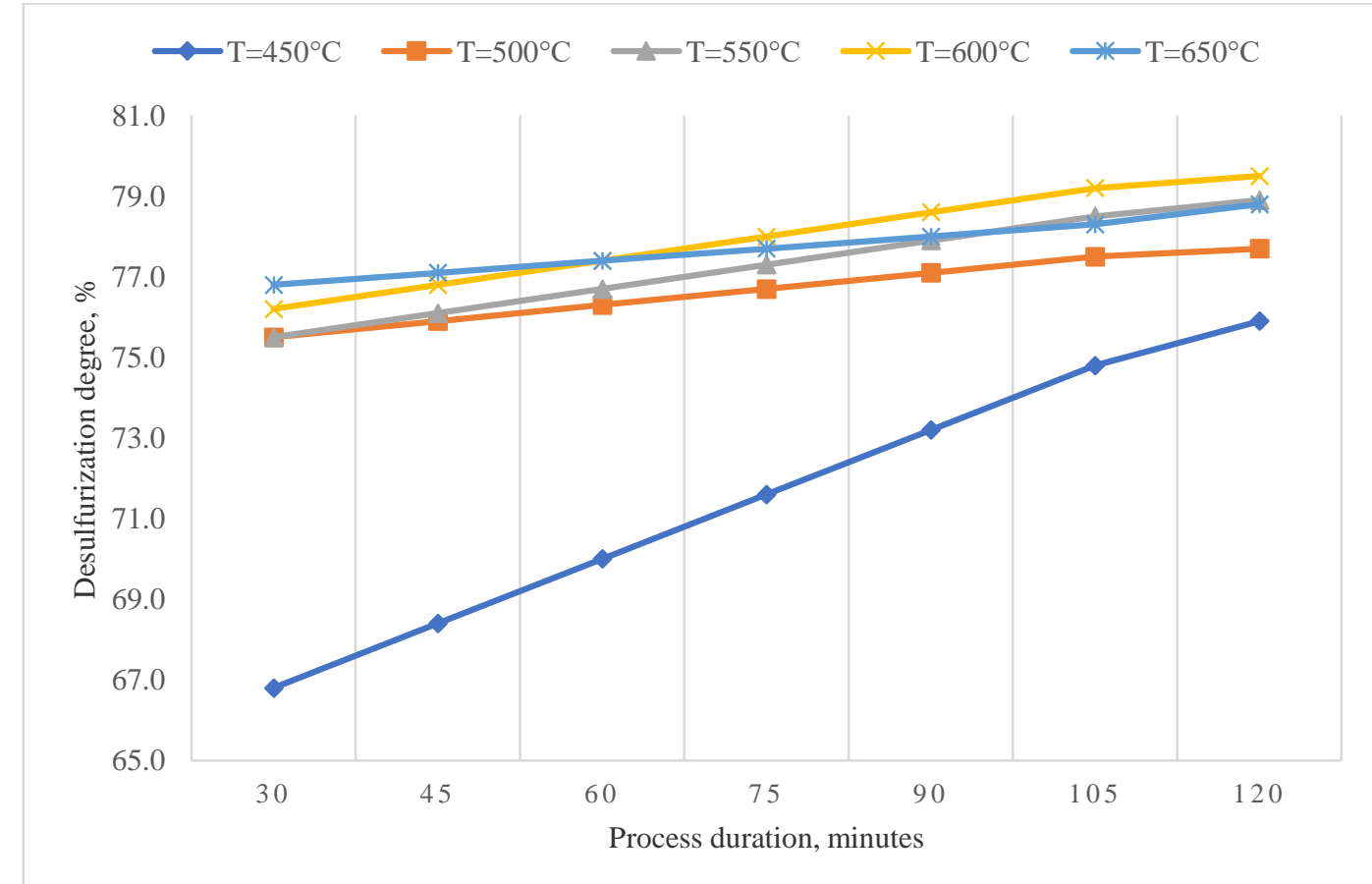

Pic.2 Dependence of the degree of extraction on the temperature and duration of the process 
The American Journal of Applied sciences

Tables 3 and 4 show the results of oxidative roasting experiments at $16 \%$ moisture content of the supplied sulfide material..

Table 3

Results of experiments on oxidative roasting of molybdenum cakes to determine the optimal mode. $\mathrm{T}=500^{\circ} \mathrm{C}, \mathrm{W}=16 \%$

\begin{tabular}{|c|c|c|c|c|c|c|}
\hline $\begin{array}{c}\text { Sample } \\
\text { No. }\end{array}$ & $\begin{array}{c}\text { Content Mo, } \\
\%\end{array}$ & Content S, \% & $\begin{array}{c}\text { Duration of } \\
\text { the } \\
\text { process, } \\
\text { minutes }\end{array}$ & $\begin{array}{c}\text { Content S, } \\
\text { after } \\
\text { roasting } \\
\text { process, } \%\end{array}$ & $\begin{array}{c}\text { Desul- } \\
\text { furization } \\
\text { degree, \% }\end{array}$ & $\begin{array}{c}\text { Extraction } \\
\text { Mo, \% }\end{array}$ \\
\hline 1 & 8,67 & 1,58 & 30 & 0,72 & 54,56 & 75,1 \\
\hline 2 & 8,67 & 1,58 & 45 & 0,69 & 56,46 & 75,7 \\
\hline 3 & 8,67 & 1,58 & 60 & 0,66 & 58,35 & 76,3 \\
\hline 4 & 8,67 & 1,58 & 75 & 0,63 & 60,25 & 76,9 \\
\hline 5 & 8,67 & 1,58 & 90 & 0,60 & 62,15 & 77,5 \\
\hline 6 & 8,67 & 1,58 & 105 & 0,57 & 64,05 & 78,1 \\
\hline 7 & 8,67 & 1,58 & 120 & 0,56 & 64,70 & 78,5 \\
\hline 8 & 8,67 & 1,58 & 135 & 0,56 & 64,7 & 78,3 \\
\hline
\end{tabular}

Table 4

Results of experiments on oxidative roasting of molybdenum cakes to determine the optimal mode. $\mathrm{T}=550^{\circ} \mathrm{C}, \mathrm{W}=16 \%$

\begin{tabular}{|c|c|c|c|c|c|c|}
\hline $\begin{array}{c}\text { Sample } \\
\text { No. }\end{array}$ & $\begin{array}{c}\text { Content Mo, } \\
\%\end{array}$ & Content S, \% & $\begin{array}{c}\text { Duration of } \\
\text { the } \\
\text { process, } \\
\text { minutes }\end{array}$ & $\begin{array}{c}\text { Content S, } \\
\text { after } \\
\text { roasting } \\
\text { process, \% }\end{array}$ & $\begin{array}{c}\text { Desul- } \\
\text { furization } \\
\text { degree, \% }\end{array}$ & $\begin{array}{c}\text { Extraction } \\
\text { Mo, \% }\end{array}$ \\
\hline 1 & 8,92 & 1,68 & 30 & 0,71 & 57,74 & 76,1 \\
\hline 2 & 8,92 & 1,68 & 45 & 0,66 & 60,54 & 78,5 \\
\hline 3 & 8,92 & 1,68 & 60 & 0,62 & 63,33 & 80,9 \\
\hline 4 & 8,92 & 1,68 & 75 & 0,57 & 66,13 & 83,3 \\
\hline
\end{tabular}


The American Journal of Applied sciences

(ISSN - 2689-0992)

Published: September 30, 2021 | Pages: 57-66

2021: 5.634

Doi: https://doi.org/10.37547/tajas/Volume03lssue09-09

OCLC - 1121105553

\begin{tabular}{|c|c|c|c|c|c|c|}
\hline $\begin{array}{c}\text { Sample } \\
\text { No. }\end{array}$ & $\begin{array}{c}\text { Content Mo, } \\
\%\end{array}$ & Content S, \% & $\begin{array}{c}\text { Duration of } \\
\text { the } \\
\text { process, } \\
\text { minutes }\end{array}$ & $\begin{array}{c}\text { Content S, } \\
\text { after } \\
\text { roasting } \\
\text { process, \% }\end{array}$ & $\begin{array}{c}\text { Desul- } \\
\text { furization } \\
\text { degree, \% }\end{array}$ & $\begin{array}{c}\text { Extraction } \\
\text { Mo, \% }\end{array}$ \\
\hline 5 & 8,92 & 1,68 & 90 & 0,52 & 68,93 & 85,7 \\
\hline 6 & 8,92 & 1,68 & 105 & 0,48 & 71,73 & 88,1 \\
\hline 7 & 8,92 & 1,68 & 120 & 0,40 & 76,20 & 91,5 \\
\hline 8 & 8,92 & 1,68 & 135 & 0,396 & 76,42 & 91,45 \\
\hline
\end{tabular}

To improve the technological parameters, we tried to conduct experiments at $700^{\circ} \mathrm{C}$. In this case, the results of oxidative firing in the newly developed installation turned out better than

in similar factory conditions. This is due to the fact that in the factory, the oxidative roasting process is carried out in rotary tube furnaces at a temperature of $550-600^{\circ} \mathrm{C}$.

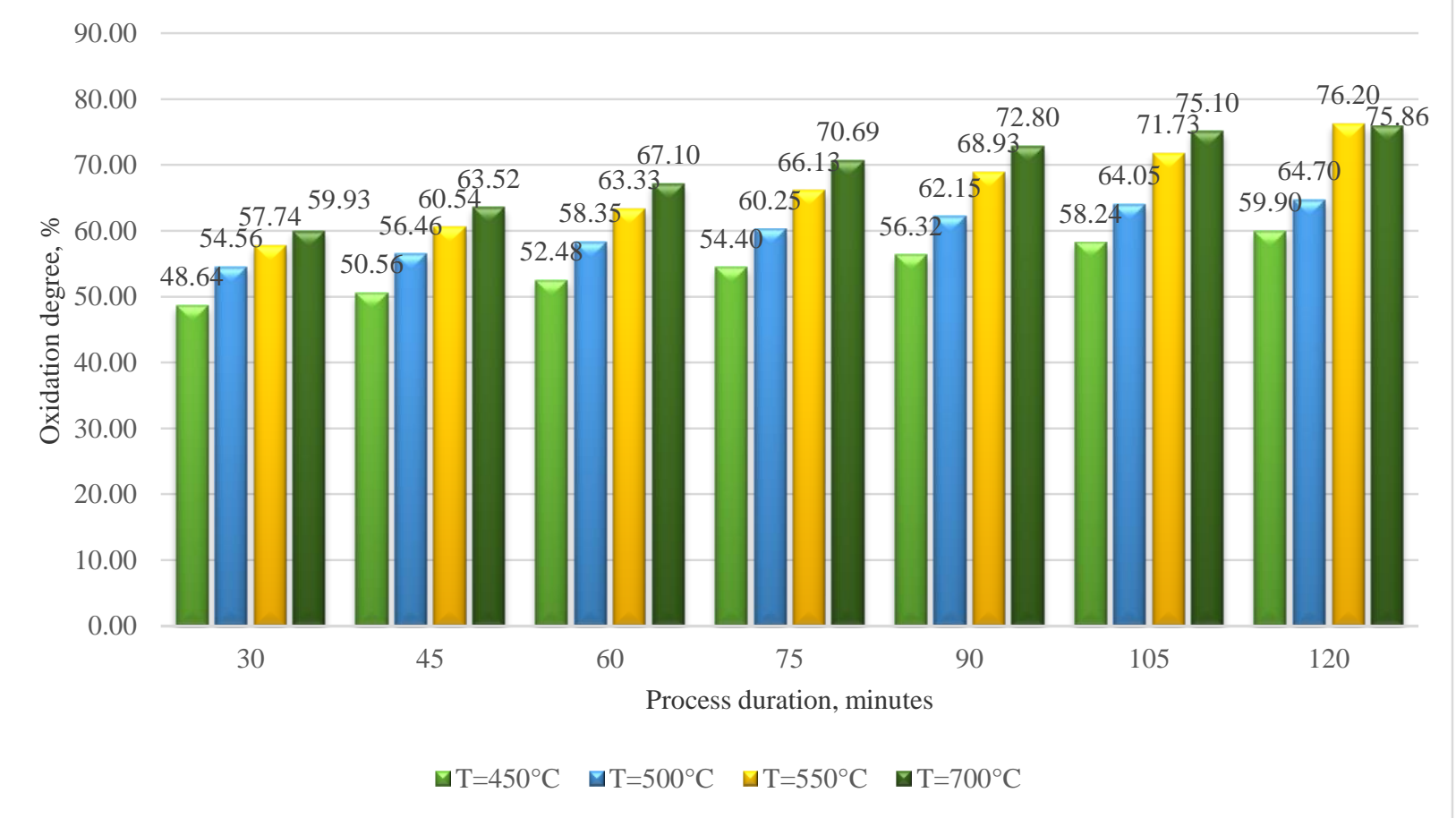

Pic.3. Influence of temperature and duration of the process on the oxidation state of sulfides

It can be seen from graph 3 that with an increase in temperature, the oxidation state of sulfides increases, but at high temperatures, more precisely, at temperatures above $650^{\circ} \mathrm{C}$, a decrease in Mo extraction is observed. Since, at high temperatures, the formation of $\mathrm{MoO}_{2}$ theoretically begins, which is insoluble during hydrometallurgical treatment. However, in the course of experiments at high temperatures in the new unit, there was no significant decrease in the recovery. Because, in the developed installation for oxidative roasting, the heat inside the furnace is not retained as in industrial installations, but is generated by using the waste heat. Consequently, this leads to an increase in oxygen and a rise in temperature. $A$ sufficient amount of oxygen prevents the 
The American Journal of Applied sciences

(ISSN - 2689-0992)

Published: September 30, 2021 | Pages: 57-66

formation of $\mathrm{MoO}_{2}$. The experimental results are shown in table 5. .

Table 5

Results of experiments on oxidative roasting of molybdenum cakes to determine the optimal mode. $\mathrm{T}=700^{\circ} \mathrm{C}, \mathrm{W}=16 \%$

\begin{tabular}{|c|c|c|c|c|c|c|}
\hline $\begin{array}{c}\text { Sample } \\
\text { No. }\end{array}$ & $\begin{array}{c}\text { Content Mo, } \\
\%\end{array}$ & Content S, \% & $\begin{array}{c}\text { Duration of } \\
\text { the process, } \\
\text { minutes }\end{array}$ & $\begin{array}{c}\text { Content S, } \\
\text { after roasting } \\
\text { process, } \%\end{array}$ & $\begin{array}{c}\text { Desul- } \\
\text { furization } \\
\text { degree, \% }\end{array}$ & $\begin{array}{c}\text { Extraction } \\
\text { Mo, \% }\end{array}$ \\
\hline 1 & 9,87 & 1,45 & 30 & 0,58 & 59,93 & 76,2 \\
\hline 2 & 9,87 & 1,45 & 45 & 0,53 & 63,52 & 76,8 \\
\hline 3 & 9,87 & 1,45 & 60 & 0,48 & 67,10 & 77,4 \\
\hline 4 & 9,87 & 1,45 & 75 & 0,43 & 70,69 & 78 \\
\hline 5 & 9,87 & 1,45 & 90 & 0,39 & 72,80 & 77,8 \\
\hline 6 & 9,87 & 1,45 & 105 & 0,36 & 75,10 & 79,2 \\
\hline 7 & 9,87 & 1,45 & 120 & 0,35 & 75,86 & 79,5 \\
\hline 8 & 9,87 & 1,45 & 135 & 0,35 & 75,86 & 79,4 \\
\hline
\end{tabular}

The main results and benefits are shown in the graphs below. (see Figures 4-5) Figure 5 shows the effect of the temperature in the furnace on the firing process and subsequently on the degree of metal recovery. The optimum temperature was $550^{\circ} \mathrm{C}$, since when the temperature inside the furnace is exceeded, the lumps begin to sinter, this leads to a further deterioration in the recovery of the valuable
component.Material with a moisture content of $12 \%$ was subjected to intensive oxidative firing at low-temperature conditions. The experiments were carried out at different temperatures and durations of the process. The experimental results are shown in the following tables. [5; c.85-88, 6; c85-86, 43; c.115]. 


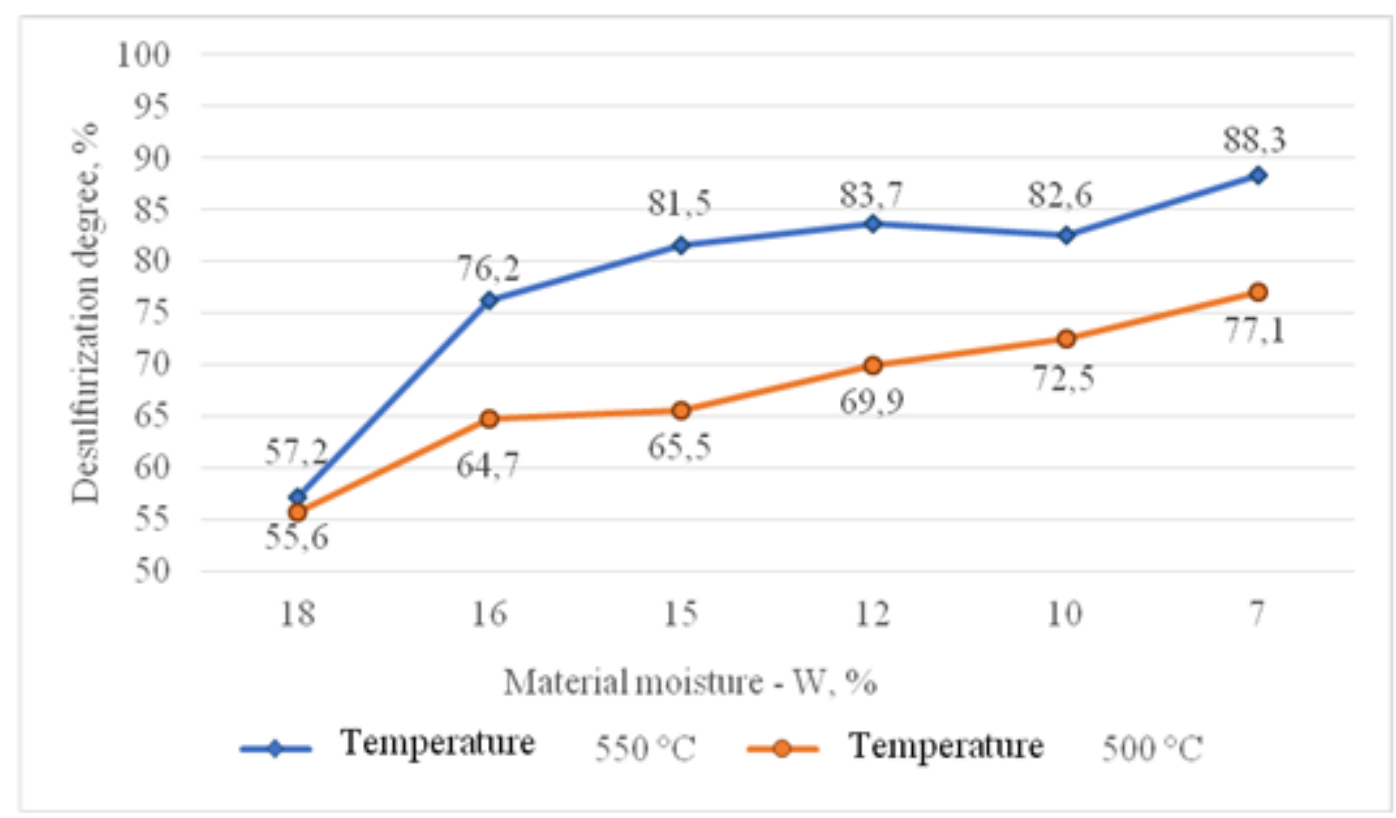

Pic.4 Dependence of sulfide oxidation on the moisture content of the feed material and the process temperature

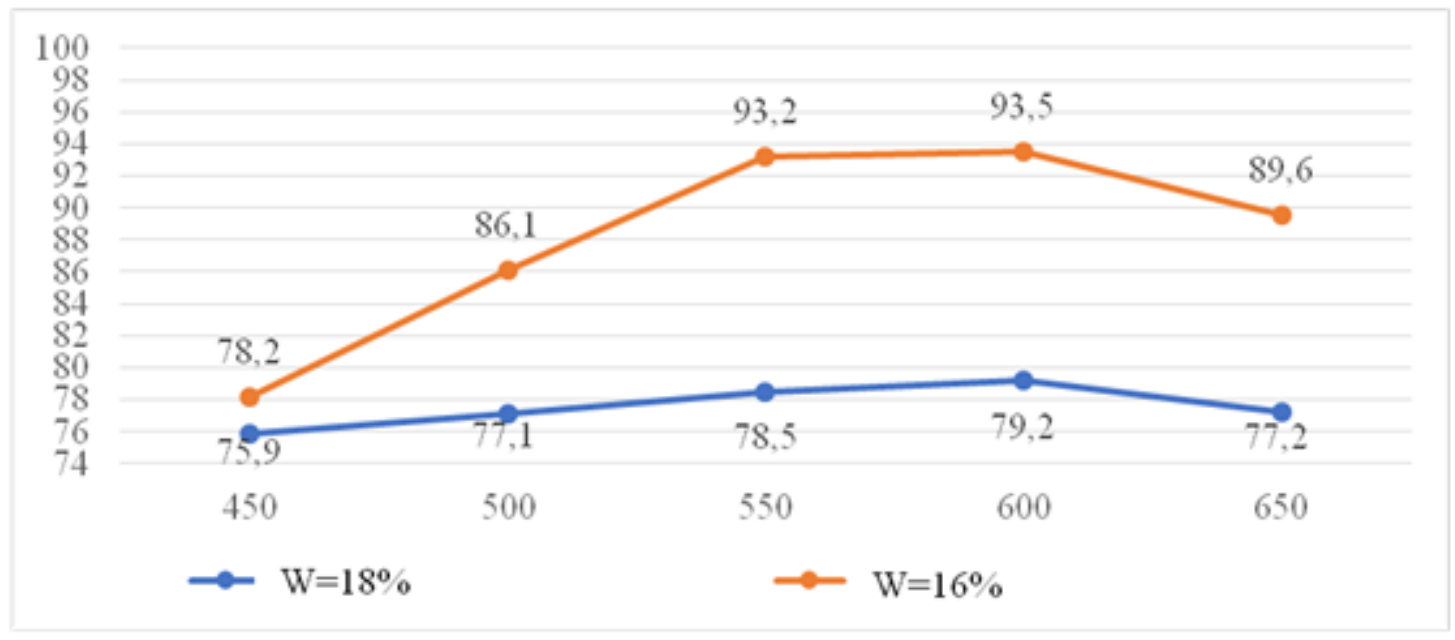

Pic.5 Influence of temperature in the furnace on the oxidative roasting process 


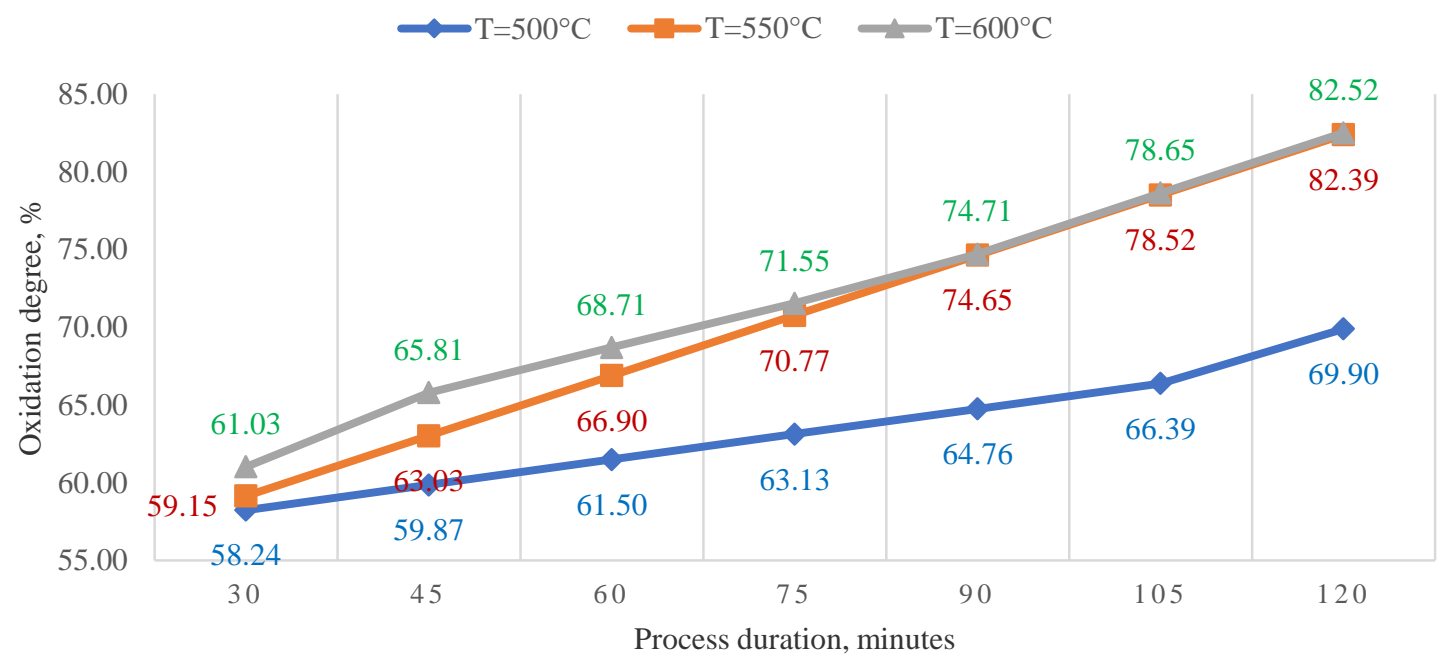

Pic. 6 Influence of the duration of the process and temperature on the oxidation state of sulfides at the moisture content of the supplied material $12 \%$

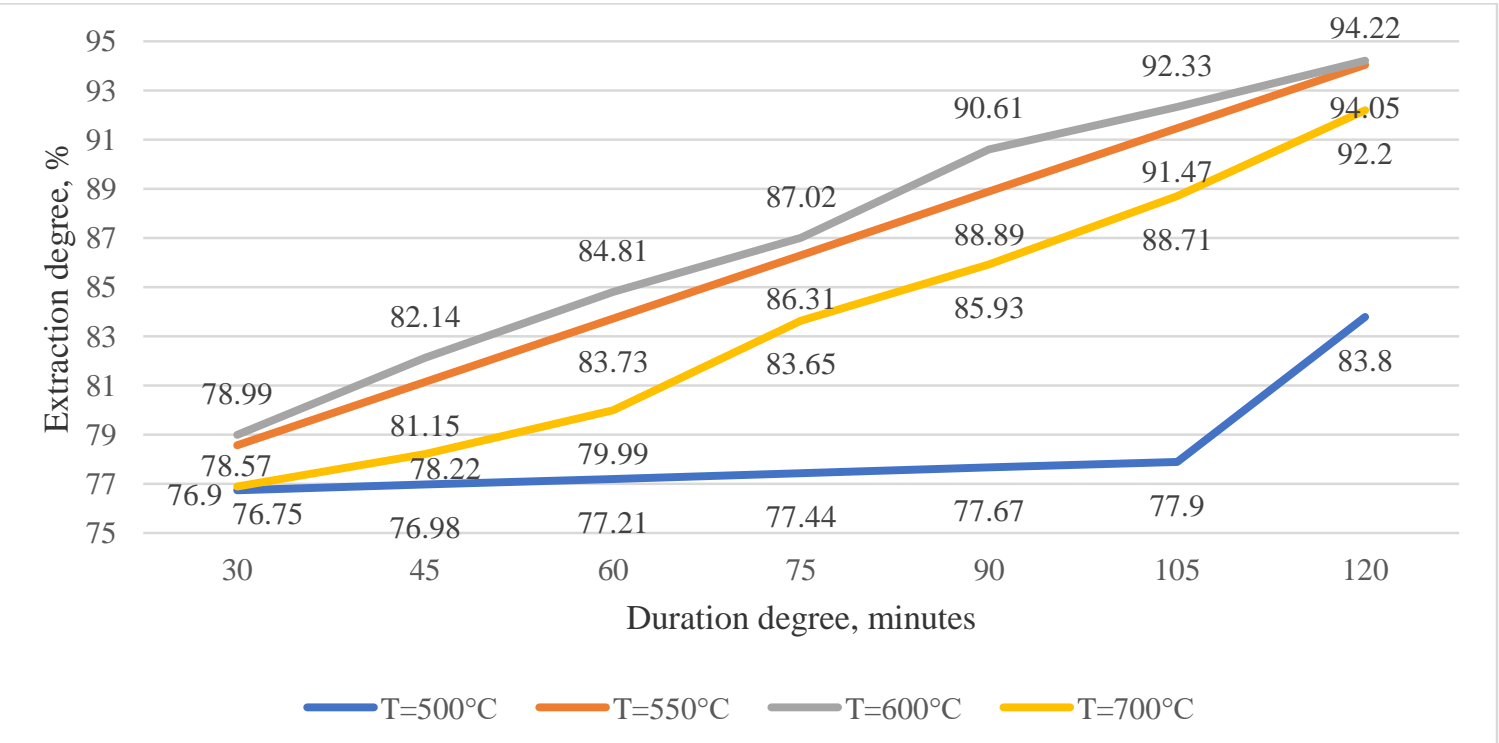

Pic.7 Influence of the process duration and temperature on the degree of recovery with the moisture content of the supplied material $12 \%$

\section{CONCLUSION}

From Figures $6-7$ it can be seen that at a temperature of $600^{\circ} \mathrm{C}$, the best results were obtained, i.e. with a process duration of 90 minutes at this temperature inside the furnace, a sulphide oxidation state of up to $74 \%$ is observed. And when oxidizing for up to 120 minutes, keeping the same temperature inside the furnace resulted in more than $82 \%$ desulfurization degree. However, the degree of extraction of molybdenum at high temperatures (above $600^{\circ} \mathrm{C}$ ) decreases, but not significantly. It should be noted that under 
industrial conditions at high oxidation temperatures, the degree of extraction of molybdenum drops sharply. This is due to a lack of oxygen during the oxidation process at the factory.

\section{REFERENCES}

1. Khasanov A.S., Tolibov B.I. Firing of molybdenum cakes in a new type of kiln for intensive firing // Mining bulletin of Uzbekistan. No. 4 (75), 2018. -P131-135.

2. Medvedev A.S., Alexandrov P.V. // Izvestiya vuzov. Non-ferrous metallurgy. 2012. No. 6. $-\mathrm{C} 15$.

3. P.V. Alexandrov, A.S. Medvedev, A.A. Kadirov, V.A. Imideev. // Izvestiya vuzov. Non-ferrous metallurgy. 2014. No. 1. -P1216.

4. Zelikman A.N., Meerson G.A. Metallurgy of rare metals. Moscow: Metallurgy, 1973. $608 \mathrm{p}$.

5. Khasanov A.S., Tolibov B.I. Investigation of the possibility of the process of oxidation of sulfide materials in a furnace for intensive roasting. Gornyi Zhurnal. No. 9, 2018 -P85-88.

6. Hasanov A.S., Tolibov B.I., Vokhidov B.R. Evaluation of operated roasting furnace operating for sulphide materials. Proceedings of international conference on Integrated innovative development of Zarafshan region: achievements, challenges and prospects, -Navoi, 26-27 October 2017. -P117-121.

7. Tolibov B.I., Hasanov A.S. Molybdenum containing products in conditions of SPA RM\&RA AMMC. Program book of the third Binational Workshop Between Korea (KIRAM) - Uzbekistan (AMMC) on Rare metals. -Chirchik. April 22, 2019. -P153

8. Hasanov A.S., Tolibov B.I., Pirnazarov F.G. Advantages of low-temperature roasting of molybdenum cakes // International scientific-practical conference on the theme: «International science review of the problems and prospects of modern science and education». - Boston, USA: 2019. - P. 17-18.

9. B.I.Tolibov, A.S.Hasanov, F.G.Pirnazarov. Molybdenum containing products processing in conditions of SPA RM\&RA AMMC // Proceedings of international conference on Integrated innovative development of Zarafshan region: achievements, challenges and prospects, -Navoi, 27-28 November 2019. -P139-143. 